\title{
Use of a maturity model for facilitating the introduction of CAR T-cell therapy-Results of the START CAR-T project
}

\author{
Stefania Bramanti', Matteo G. Carrabba ${ }^{2}$, Alice Di Rocco ${ }^{3}$, Elena Fabris ${ }^{4}$, Luca Gastaldi ${ }^{4}$, Paolo Locatelli ${ }^{4}$, Maria Chiara Tisi ${ }^{5}$ \\ ${ }^{1}$ BMT Unit, IRCCS Humanitas Research Hospital, Rozzano - Italy \\ ${ }^{2}$ Hematology and Bone Marrow Transplantation Unit, IRCCS San Raffaele Scientific Institute, Milan - Italy \\ ${ }^{3} \mathrm{COU}$ Hematology, AOU Policlinico Umberto I, Rome - Italy \\ ${ }^{4}$ Department of Management, Economics and Industrial Engineering (DIG), Politecnico di Milano, Milan - Italy \\ ${ }^{5}$ Cell Therapy and Hematology, San Bortolo Hospital, Vicenza - Italy
}

\begin{abstract}
Introduction: Chimeric antigen receptor (CAR) T-cell therapies are novel immunotherapies for the treatment of hematologic malignancies. They are administered in specialized centers by a multidisciplinary team and require the careful coordination of all steps involved in manufacturing and using cellular therapies. The Maturity Model (MM) is a tool developed and used for assessing the effectiveness of a variety of activities. In healthcare, it may assist clinicians in the gradual improvement of patient management with CAR T-cell therapy and other complex treatments.

Methods: The START CAR-T project was initiated to investigate the potential of a MM in the setting of CAR T-cell therapy. Four Italian clinics participated in the creation of a dedicated MM. Following the development and test of this MM, its validity and generalizability were further tested with a questionnaire submitted to 18 Italian centers. Results: The START CAR-T MM assessed the maturity level of clinical sites, with a focus on organization, process, and digital support. For each area, the model defined four maturity steps, and indicated the actions required to evolve from a basic to an advanced status. The application of the MM to 18 clinical sites provided a description of the maturity level of Italian centers with regard to the introduction of CAR T-cell therapy.

Conclusion: The START CAR-T MM appears to be a useful and widely applicable tool. It may help centers optimize many aspects of CAR T-cell therapy and improve patient access to this novel treatment option.

Keywords: Digital transformation, Hematological immunotherapy, Healthcare management, Innovation, Maturity Model
\end{abstract}

\section{Introduction}

Chimeric antigen receptor (CAR) T-cell therapy is the most advanced immunotherapeutic strategy currently available for the treatment of hematologic malignancies (1). This personalized strategy involves several steps including the isolation of autologous T cells from the patient, their modification via retroviral transduction with a CAR construct, the expansion of the CAR-expressing T cells, and, finally, the infusion of the

Received: September 9, 2021

Accepted: December 6, 2021

Published online: January 8, 2022

\section{Corresponding author:}

Paolo Locatelli

Department of Management,

Economics and Industrial Engineering (DIG)

Politecnico di Milano

Via Lambruschini, 4/B, 20156 Milano MI

Milan - Italy

paolo.locatelli@polimi.it modified cells back into the patient $(2,3)$. CARs are fusion proteins that contain an extracellular antibody-derived domain for the recognition of a specific antigen on the surface of tumor cells (e.g., CD19 on malignant B cells), an intracellular primary signaling domain leading to T-cell activation, and an intracellular costimulatory domain to promote effector T-cell functions $(2,3)$.

Due to the novelty and complexity of CAR T-cell therapies, their manufacturing and adoption in clinical practice impose several new regulatory and organizational challenges. The European Medicines Agency (EMA) classifies these therapies as Advanced Therapy Medicinal Products (ATMPs), which can be administered only in centers with documented experience with hematopoietic stem cell transplantation (HSCT) and novel immunotherapies (4). The Joint Accreditation Committee ISCT (International Society for Cellular Therapy)Europe (JACIE) has developed a series of quality standards for CAR T-cell therapy administration (5). In terms of personnel and infrastructure, qualified centers should comprise a multidisciplinary team and several highly coordinated units (hematology, transfusion, intensive care, emergency care, and neurology) (4). 
The quality of healthcare is influenced by the maturity of the processes used to develop it (6). A Maturity Model (MM) can be useful for the assessment and improvement of organizational processes. MMs are used as an evaluative and comparative basis for improvement, designed to assess the maturity of a selected domain based on a more or less comprehensive set of criteria $(7,8)$. Maturity, thus, implies an evolutionary progress in the accomplishment of a target-from an initial to a desired or normally occurring end stage (9). MMs are used to assess as-is situations, to guide improvement initiatives and to control progress $(10,11)$. The purpose of an MM can be categorized as descriptive, prescriptive, or comparative (7). A descriptive MM is applied for as-is assessments; a prescriptive MM is applied to guide organizations in the identification of desirable future maturity levels, highlighting how to reach them according to improvement measures; a comparative $\mathrm{MM}$ allows benchmarking across industries and regions (7).

The START CAR-T project was conceived to facilitate the introduction of CAR T-cell therapy in Italy. An MM was developed within this project, to evaluate the maturity and performance of Italian centers with regard to CAR T-cell therapy use. This article presents the START CAR-T MM.

\section{Methods}

The development of the START CAR-T MM started with the definition of the scope and domain to which the MM would be targeted and applied (7). In particular, the identification of the most coherent organizational model for the introduction of CAR T-cell therapy in clinical sites was set as the final scope.

The second phase of MM development, in accordance with de Bruin et al (7), was the design of the model. Due to the novelty of CAR T-cell therapy in Italy, four different
Italian clinical centers were involved, which had either a JACIE accreditation or a commercial qualification for CAR T-cell therapy. The selected clinical sites, represented by the directors of the CAR T-cell therapy unit, were among the first centers to adopt this therapy in Italy (Istituto Clinico Humanitas, Milano; IRCCS Ospedale San Raffaele, Milano; Policlinico Umberto I, Roma; and Ospedale San Bortolo, Vicenza). The interaction with these clinical sites allowed to: (1) map the current treatment pathway with CAR T-cell therapy; (2) outline the various therapy administration methods and the patients' needs; (3) highlight the organizational patterns and the presence of digital solutions to support the management processes. From this interaction and the analysis of CAR T-cell therapy management and pathways of patient care, it was possible to define the MM shown in Figure 1. The proposed MM is divided into three macro-categories: "Organization" that looks at the configuration of practitioners and their interaction methods in the process of CAR T-cell therapy; "Process" that synthesizes activities addressed to define and implement pathways of treatment with CAR T-cell therapies; "Digital support" that investigates the presence of digital solutions to support the management of CAR T-cell therapies. Each macrocategory is composed of different sub-components, called variables mutually exclusive and collectively exhaustive, which describe in depth features of each macro-category. The maturity of a clinical site can be investigated by positioning it into one of the four maturity stages that describe variables, from a basic (level 1 ) to an advanced stage (level $4)$, defined in accordance with the clinical sites. Along with the variables, a Hub \& Spoke Network was also investigated due to the importance of collaborative healthcare networks and the alliance of professionals and/or institutions for providing patients with fair and equal opportunities of access to healthcare (12).

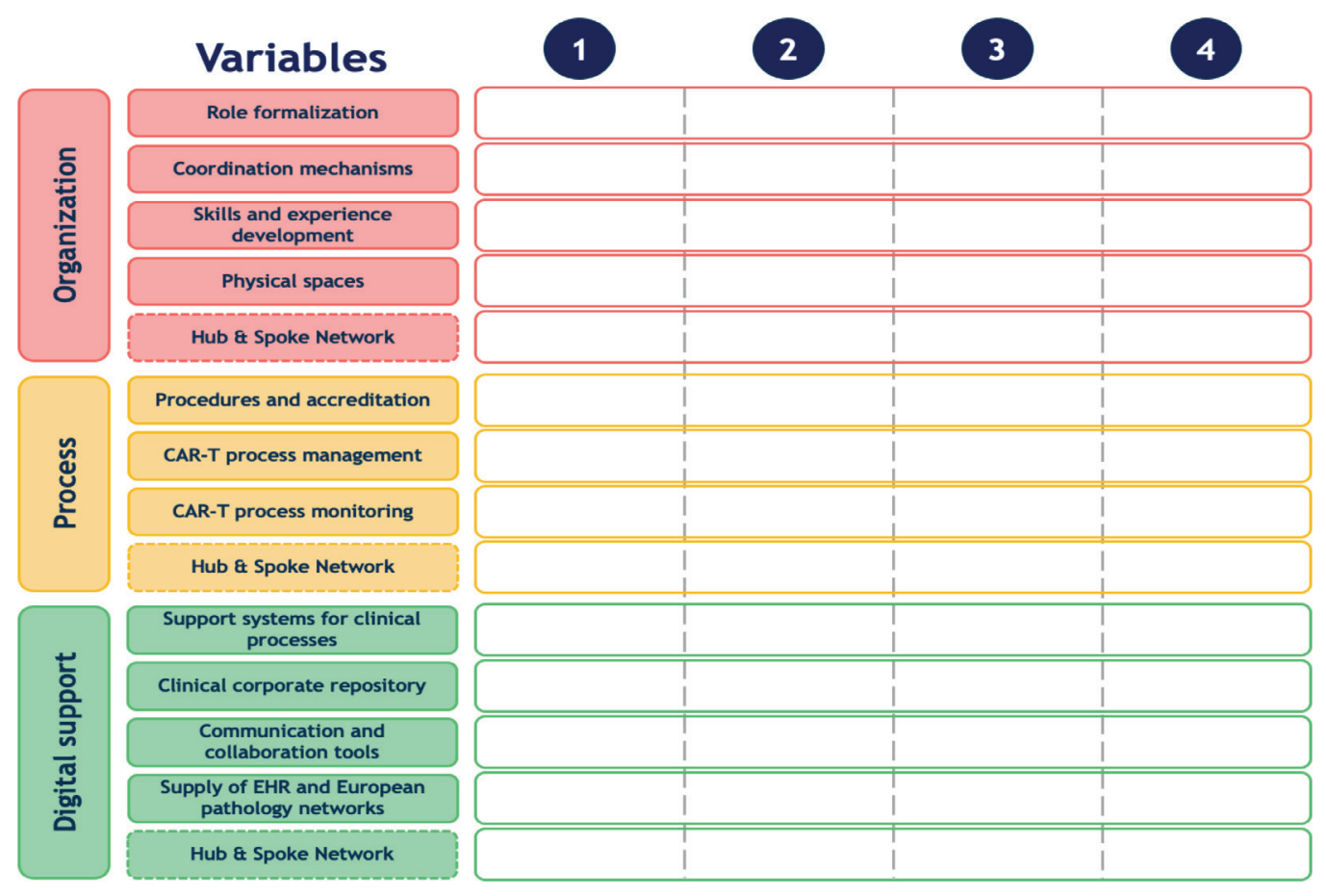

Fig. 1 - Maturity Model scheme composed of three macrocategories, 14 variables (rows) and 4 maturity steps (columns). 
The first macro-category-Organization-reflects the importance of organizational strategies in healthcare systems, due to the increased uncertainty and variety hospitals are facing (13). Variables included in this macro-category are:

- Role formalization, which deals with the presence of medical center staff (e.g., doctors, biologists, nurses) specifically dedicated to the management of the care pathway of patients treated with CAR T-cell therapy and the role conferred to them.

- Coordination mechanism, which investigates the coordination modalities used by the team dedicated to the management of the care pathway of patients treated with CAR T-cell therapy in order to define strategies and share information.

- Skills and experience development, which investigates the type of courses provided, the skills and experience acquired by the personnel, all fundamental elements when new therapies are introduced.

- Physical spaces, which deal with the spaces dedicated to patients treated with CAR T-cell therapy; these spaces could be shared with the transplantation department or could be devoted exclusively to the management of CAR T-cell recipients, throughout the entire process.

- Hub \& Spoke Network, which investigates the presence of formal and informal agreements with other clinical sites regarding the delegation of one or more phases of the therapy process.

The second macro-category-Process-addresses the activities implemented in the care pathway of patients treated with CAR T-cell therapy, for example, to limit waste of time and space and improve the management capacity of clinical sites (14). This macro-category is composed of four different variables:

- Procedures and accreditation: to introduce CAR T-cell therapy, Italian clinical sites need to acquire a recognized certification of quality, including the National Transplant Centre certification, the qualification by the provider of the cellular therapy, a regional accreditation, and the JACIE accreditation (or submission to obtain it). Clinical sites could also introduce specialized procedures, coherent and homogeneous with the existing ones.

- CAR-T process management, which addresses the postinfusion monitoring phase that can take place inside the intensive care unit or the transplantation department, while the transfer of patient to the intensive care unit is reserved only to cases with major complications.

- CAR-T process monitoring, which monitors a panel of clinical indicators to evaluate the care of patients treated with CAR T-cell therapy, as requested by current legislations and the JACIE.

- Hub \& Spoke Network, which evaluates phases of CAR T-cell therapy that can be delegated to other sites.

Digitalization has become crucial for healthcare organization, not only due to its increasing pervasiveness but also due to its ability to respond to the challenges imposed by innovation, including rationalization of healthcare costs and increase in the quality of processes (15). The last macrocategory-Digital support-is composed of the following five variables:

- The presence of support systems for clinical processes such as an Electronic Medical Record and its features, and the digital solutions used to manage CAR T-cell therapy.

- The presence of a clinical corporate repository and the type of documents and data collected by this solution; the grade of interoperability of the repository is also investigated.

- Communication and collaboration tools used within the clinical site to enable the communication between medical staff.

- The ability of clinical sites to supply the Electronic Health Record and European pathology networks (i.e., ProMISe, https://www.ebmt.org/registry/data-collection-car-tcells) with information about the care pathway of patients treated with CAR T-cell therapy.

- The use of digital solutions within the Hub \& Spoke Network that permits interactions between the clinical sites and their Spoke centers.

The four clinical sites were involved also in a first test of the validity of the developed MM. In particular, applying the Plan-Do-Check-Act (PDCA) cycle inspired in 1950 by Deming (16), it was possible to evaluate the capability of the MM to investigate salient organizational, procedural, and digital support features used to manage CAR T-cell therapy and patient care pathways. After the intervention made to improve the validity of the MM, the tool was applied again and discussed within clinical sites to assess its reliability.

Following the test phase, a survey was performed to extend the MM use to a broader number of clinical sites and to evaluate its generalizability. The survey was based on the salient elements of the MM, which were formulated into a questionnaire. Clinical sites were asked to evaluate the maturity of their processes by assigning a score from 1 to 4 to each variable of the MM questionnaire. The survey questionnaire was made available via a dedicated Internet website to 18 Italian clinical sites, selected so as to cover the entire national territory. The sites involved in the survey included public and private clinics, as well as centers at different stages of the accreditation process required for using CAR T-cell therapy. The results of the survey about the MM tool developed within the START CAR-T project were analyzed in the last phase of the project.

\section{Results}

The MM developed within the START CAR-T project to evaluate the effectiveness of CAR T-cell therapy centers was submitted to 18 Italian clinical sites. In the following paragraphs, the survey results are discussed according to the MM macro-categories.

\section{Organization}

According to the results of the survey, Italian clinical sites have gained a medium-high positioning into different variables of the organizational macro-category (Fig. 2). In 


\begin{tabular}{|c|c|c|c|c|}
\hline & 1 & 2 & 3 & 4 \\
\hline $\begin{array}{c}\text { Role } \\
\text { formalization }\end{array}$ & $\begin{array}{l}\text { Medical center staff (e.g. doctors, biologists, } \\
\text { nurses,...) is not specifically dedicated to } \\
\text { manage the care path of the patient treated } \\
\text { with CAR-T therapy } \\
0 \%\end{array}$ & $\begin{array}{l}\text { Medical center staff (e.g. doctors, biologists, } \\
\text { nurses, ...) is specifically dedicated to } \\
\text { manage the care path of the patient treated } \\
\text { with CAR-T therapy } \\
6 \%\end{array}$ & $\begin{array}{l}\text { Presence of a CAR-T director who is charged } \\
\text { with the decision-making and directional role } \\
\text { during the care path of the patient treated } \\
\text { with CAR-T therapy } \\
\text { Presence of a CAR-T coordinator who, as a } \\
\text { case manager, supervises and coordinates } \\
\text { the entire care path of the patient treated } \\
\text { with CAR-T therapy } \\
17 \%\end{array}$ & $\begin{array}{l}\text { Formalization of a CAR-Team with defined } \\
\text { roles and activities for each specific } \\
\text { component of the care path. } \\
\text { The medical center staff (e.g. doctors, } \\
\text { biologists, nurses, ...), specifically dedicated } \\
\text { to managing the care path of the patient } \\
\text { treated with CAR-T therapy, is appropriately } \\
\text { sized with respect to the management needs } \\
77 \%\end{array}$ \\
\hline $\begin{array}{c}\text { Coordination } \\
\text { mechanisms }\end{array}$ & $\begin{array}{l}\text { The transplantation department staff } \\
\text { organizes monodisciplinary meetings in order } \\
\text { to share and discuss aspects related to the } \\
\text { care path of the patient treated with CAR-T } \\
\text { therapy and the cellular therapy } \\
\text { management. Other professionals (e.g. } \\
\text { radiologists, trauma surgeons, pharmacists, } \\
\text { biologists) may be involved separately, } \\
\text { outside the disciplinary meetings } \\
6 \%\end{array}$ & $\begin{array}{l}\text { Other professionals (e.g. radiologists, trauma } \\
\text { surgeons, pharmacists, biologists), that play } \\
\text { an active role during the care path of patient } \\
\text { treated with CAR-T therapy and in managing } \\
\text { the cellular therapy, are occasionally } \\
\text { involved in the transplantology staff's } \\
\text { meetings } \\
22 \%\end{array}$ & $\begin{array}{c}\text { Presence of codified multidisciplinary } \\
\text { meetings, dedicated to discuss and share the } \\
\text { care path of patient treated with CAR-T } \\
\text { therapy and to the cellular therapy } \\
\text { management. Experts from different medical } \\
\text { disciplines regularly attend these meetings } \\
11 \%\end{array}$ & $\begin{array}{l}\text { Presence of multidisciplinary collegial } \\
\text { meetings which, thanks to thy presence of } \\
\text { the CAR-T coordinator, are dedicated to } \\
\text { making strategic decisions for the care path } \\
\text { of the patient treated with CAR-T therapy and } \\
\text { for the management of the cellular therapy } \\
61 \%\end{array}$ \\
\hline $\begin{array}{c}\text { Skills and } \\
\text { experience } \\
\text { development }\end{array}$ & $\begin{array}{l}\text { Training courses are provided to the main } \\
\text { representatives of the transplantation } \\
\text { department, since the start-up phase of the } \\
\text { therapy, with a training renewal according to } \\
\text { a continuous training program } \\
6 \%\end{array}$ & $\begin{array}{l}\text { Frequent training courses are provided to all } \\
\text { staff expressly dedicated to the } \\
\text { management of patients treated with CAR-T } \\
\text { therapy and to cellular therapy management, } \\
\text { allowing them to develop sufficient skills to } \\
\text { operate independently. Systems for verifying } \\
\text { the training level are also present } \\
28 \%\end{array}$ & $\begin{array}{l}\text { All staff expressly dedicated to the } \\
\text { management of patients treated with CAR-T } \\
\text { therapy and to cellular therapy management, } \\
\text { is able to operate in complete autonomy } \\
\text { thanks to the skills developed. Qualified } \\
\text { staff from other medical centers are also } \\
\text { involved in the trainings. Are present specific } \\
\text { procedures for maintaining the training level } \\
55 \%\end{array}$ & $\begin{array}{l}\text { The medical center has developed skills in } \\
\text { order to be recognized as a reference at } \\
\text { national level and to carry out «tutoring" } \\
\text { and «on the job» support for other medical } \\
\text { centers } \\
11 \%\end{array}$ \\
\hline Physical spaces & $\begin{array}{l}\text { The physical spaces used for the care path of } \\
\text { the patient treated with CAR-T therapy are } \\
\text { shared with spaces used for other } \\
\text { transplantation department activities } \\
11 \%\end{array}$ & $\begin{array}{l}\text { Expected additional dedicated beds for } \\
\text { patients treated with CAR-T therapy } \\
\qquad 39 \%\end{array}$ & $\begin{array}{l}\text { Presence of a CAR-T clinic with dedicated } \\
\text { spaces for the patients' management in } \\
\text { some specific phases of the care path (e.g. } \\
\text { initial assessment, training activities, } \\
\text { monitoring in the follow-up phase, etc.) } \\
6 \%\end{array}$ & $\begin{array}{l}\text { Presence of a CAR-T clinic with dedicated } \\
\text { spaces for the patients' management in all } \\
\text { phases of the care path (e.g. initial } \\
\text { assessment, training activities, monitoring in } \\
\text { the follow-up phase, etc.). Accommodations } \\
\text { near the clinical center available for patients } \\
44 \%\end{array}$ \\
\hline
\end{tabular}

Fig. 2 - Organization macro-category: description of different maturity steps for each variable and rates of centers for each variable and maturity level.

particular, clinical sites, with no distinction between those that already used CAR T-cell therapy and those that were concluding the accreditation phase, formalized roles of personnel involved in therapy management. In the majority of cases (77\%), a CAR T-cell therapy team, including a director, a coordinator, and a case manager, was defined. As for the presence of coordination mechanisms, $61 \%$ of clinical sites defined multidisciplinary meetings, where strategic decisions for CAR T-cell therapy and care pathways were made; only a minority of centers (22\%) organized monodisciplinary meetings. In $66 \%$ of clinical sites, courses directed to the personnel involved in therapy management were established and a continuous educational program was ongoing; $11 \%$ of clinical sites had achieved a level of expertise that allowed them to provide educational courses to other Italian clinical sites. With regard to physical spaces, half of the clinical sites established a clinic for CAR T-cell therapy, where the entire care pathway or part of it took place. The remaining clinical sites had no dedicated spaces, but had a number of beds reserved for patients treated with CAR T-cell therapy.

\section{Process}

A high level of maturity was shown in two of the three variables of this macro-category (Fig. 3). In particular, $88 \%$ of clinical sites had defined procedures dedicated to CAR T-cell therapy and patient care pathways; $66 \%$ had harmonized them with existing procedures. The postinfusion monitoring phase was managed in $78 \%$ of clinical sites in the transplantation department, with the transfer of patients being planned only in case of major complications. The access to the intensive care unit was guaranteed thanks to previous agreements between departments. Clinical sites introduced monitoring tool dedicated to clinical features of CAR T-cell therapy and care pathway $(50 \%)$; only in few cases were economic $(22 \%)$ or economic and organizational issues (22\%) monitored. In clinical practice, these issues frequently limit the provision of appropriate therapies (17).

\section{Digital support}

As shown in Figure $4,83 \%$ of the clinical sites had an Electronic Medical Record; 55\% had advanced features and mobile technologies, reflecting the increasing importance of ICT in healthcare (18). Notably, $17 \%$ of clinical sites were still using paper-based records. Support systems used for CAR T-cell therapy, like prescription and administration, allowed a digital management of these procedures (72\%); in $22 \%$ of cases the digital tools supported logistic and administrative management. A clinical corporate repository collected 


\begin{tabular}{|c|c|c|c|c|}
\hline & 1 & 2 & 3 & 4 \\
\hline $\begin{array}{l}\text { Procedures and } \\
\text { accreditation }\end{array}$ & $\begin{array}{l}\text { Obtaining the certification of the National } \\
\text { Transplant Center and the center } \\
\text { qualification by the provider of the cellular } \\
\text { therapy. Request for JACIE European } \\
\text { accreditation or request for re-accreditation. } \\
\text { Obtaining the regional accreditation } \\
6 \%\end{array}$ & $\begin{array}{l}\text { Completed achievement of the current } \\
\text { European JACIE accreditation. Presence of } \\
\text { defined and dedicated procedures } \\
\text { throughout the care path of the patient } \\
\text { treated with CAR-T therapy and for the } \\
\text { cellular therapy management } \\
6 \%\end{array}$ & $\begin{array}{l}\text { Presence of specialized procedures, within } \\
\text { the company procedures, } \\
\text { for the care path of the patient treated with } \\
\text { CAR-T therapy and for the cellular therapy } \\
\text { management } \\
22 \%\end{array}$ & $\begin{array}{l}\text { Presence of specialized procedures, coherent } \\
\text { and homogeneous with the company } \\
\text { procedures, for the care path of the patient } \\
\text { treated with CAR-T therapy and for the } \\
\text { cellular therapy management } \\
66 \%\end{array}$ \\
\hline $\begin{array}{l}\text { CAR-T process } \\
\text { management }\end{array}$ & $\begin{array}{l}\text { The post-infusion monitoring phase of the } \\
\text { CAR-T therapy is always managed in the } \\
\text { intensive care unit } \\
0 \%\end{array}$ & $\begin{array}{l}\text { Presence of intensive care operators who } \\
\text { can intervene directly in the ward in case of } \\
\text { minor complications. They can also train } \\
\text { ward staff in developing specific skills. For } \\
\text { major complications the patient is } \\
\text { transferred to the intensive care } \\
0 \%\end{array}$ & $\begin{array}{l}\text { Doctors and nurses of the transplantation } \\
\text { department have basic resuscitation skills } \\
\text { and transfer the patient into the intensive } \\
\text { care only in the case of major complications } \\
\text { (which normatively require to be managed in } \\
\text { the intensive care) } \\
22 \%\end{array}$ & $\begin{array}{c}\text { Use of intensive care beds with priority } \\
\text { access for CAR-T patients, only in those cases } \\
\text { that cannot be managed in the ward } \\
78 \%\end{array}$ \\
\hline $\begin{array}{l}\text { CAR-T process } \\
\text { monitoring }\end{array}$ & $\begin{array}{l}\text { Monitoring of clinical indicators, required by } \\
\text { the current legislation and by the European } \\
\text { JACIE accreditation, related to the care } \\
\text { process of the patient treated with CAR-T } \\
\text { therapy and to the cellular therapy } \\
\text { management } \\
6 \%\end{array}$ & $\begin{array}{l}\text { The medical center monitors additional } \\
\text { clinical indicators internally defined, } \\
\text { expressly developed for monitoring the care } \\
\text { path of the patient treated with CAR-T } \\
\text { therapy and the management of the cellular } \\
\text { therapy } \\
50 \%\end{array}$ & $\begin{array}{l}\text { Use of a dashboard of clinical and economic } \\
\text { indicators specifically developed for } \\
\text { monitoring the care path of the patient } \\
\text { treated with CAR-T therapy and the } \\
\text { management of the cellular therapy } \\
22 \%\end{array}$ & $\begin{array}{l}\text { Use of a dashboard of indicators that } \\
\text { considers also time and quality aspects, } \\
\text { expressly developed for monitoring the care } \\
\text { path of the patient treated with CAR-T } \\
\text { therapy and the management of the cellular } \\
\text { therapy } \\
22 \%\end{array}$ \\
\hline
\end{tabular}

Fig. 3 - Process macro-category: description of different maturity steps for each variable and rates of centers for each variable and maturity level.

\begin{tabular}{|c|c|c|c|c|}
\hline & 1 & 2 & 3 & 4 \\
\hline $\begin{array}{l}\text { Clinical support } \\
\text { systems }\end{array}$ & $\begin{array}{l}\text { CAR-T medical records and CAR-T specific } \\
\text { forms are completely paper-based: only some } \\
\text { specific clinical documents (e.g., medical } \\
\text { reports) are managed digitally } \\
17 \%\end{array}$ & $\begin{array}{l}\text { Presence of an Electronic Medical Record (EMR) } \\
\text { where the basic data of the care path of the } \\
\text { patient treated with CAR-T therapy are stored } \\
\text { (e.g., management of patient summary } \\
\text { information, consultation of medical reports } \\
\text { and images) } \\
28 \%\end{array}$ & $\begin{array}{l}\text { Presence of an EMR with advanced features } \\
\text { (e.g., detection of vital parameters from } \\
\text { monitoring equipment) for the management of } \\
\text { information generated along the care path of } \\
\text { the patient treated with CAR-T therapy. } \\
\text { Moreover, the EMR is usable on mobile support } \\
55 \%\end{array}$ & $\begin{array}{l}\text { Presence of decision support systems (e.g., for } \\
\text { identifying patients potentially eligible for the } \\
\text { CAR-T therapy, for monitoring post-infusion } \\
\text { complications, ...) or Artificial Intelligence } \\
\text { systems capable of autonomously implementing } \\
\text { the proposed actions according to the results of } \\
\text { the carried out analyzes } \\
0 \%\end{array}$ \\
\hline $\begin{array}{l}\text { Management of } \\
\text { CAR-T therapy } \\
\text { support systems }\end{array}$ & $\begin{array}{l}\text { CAR-T therapy specific forms are completely } \\
\text { paper-based except for digital platform from } \\
\text { medical provider } \\
6 \%\end{array}$ & $\begin{array}{l}\text { Presence of a pharmacy application for logistic- } \\
\text { administrative management (e.g., calculation of } \\
\text { the need and verification of the corresponding } \\
\text { availability, verification of the stocks, etc.) } \\
22 \%\end{array}$ & $\begin{array}{l}\text { Digitized management (e.g., prescription, } \\
\text { administration) of the CAR-T cellular therapy } \\
55 \%\end{array}$ & $\begin{array}{l}\text { Digitized management (e.g., prescription, } \\
\text { administration) of the CAR-T cellular therapy } \\
\text { and Integration with the digital platform } \\
\text { provided by the cellular therapy provider } \\
17 \%\end{array}$ \\
\hline $\begin{array}{l}\text { Clinical corporate } \\
\text { repository }\end{array}$ & $\begin{array}{l}\text { Presence of a clinical corporate repository } \\
\text { where some clinical documents (e.g., medical } \\
\text { reports, discharge letters) of patients treated } \\
\text { with CAR-T therapy are collected } \\
22 \%\end{array}$ & $\begin{array}{c}\text { Presence of a clinical corporate repository } \\
\text { where all the clinical documents of patients } \\
\text { treated with CAR-T therapy are collected } \\
39 \%\end{array}$ & $\begin{array}{l}\text { Presence of a clinical corporate repository } \\
\text { where all documents and structured clinical } \\
\text { data of patients treated with CAR-T therapy are } \\
\text { collected } \\
22 \%\end{array}$ & $\begin{array}{l}\text { Presence of an integrated and interoperable } \\
\text { corporate repository based on the use of } \\
\text { standards with respect to the different } \\
\text { applications for the management of patients } \\
\text { treated with CAR-T therapy } \\
17 \%\end{array}$ \\
\hline $\begin{array}{l}\text { Communication } \\
\text { and collaboration } \\
\text { tools }\end{array}$ & $\begin{array}{l}\text { Communications between medical center staff } \\
\text { involved in the care path of the patient treated } \\
\text { with CAR-T therapy take place in an } \\
\text { unstructured way (e.g, telephone, email, } \\
\text { Skype, ...). Furthermore, the medical center has } \\
\text { access to the digital platform provided by the } \\
\text { cellular therapy provider } \\
6 \%\end{array}$ & $\begin{array}{l}\text { Communications between medical center staff } \\
\text { involved in the care path of the patient treated } \\
\text { with CAR-T therapy take place in an } \\
\text { unstructured way; nonetheless there is a digital } \\
\text { support in order to keep track of all the } \\
\text { interactions exchanged during the care path of } \\
\text { the CAR-T therapy } \\
55 \%\end{array}$ & $\begin{array}{l}\text { Communications between medical center staff } \\
\text { involved in the care path of the patient treated } \\
\text { with CAR-T therapy take place in a structured } \\
\text { way (e.g., EMR, internal management, } \\
\text { teleconsulting platforms to share documents } \\
\text { and images, ...) } \\
33 \%\end{array}$ & $\begin{array}{l}\text { Presence of decision-making workflows that } \\
\text { include communications between medical } \\
\text { center staff through digital support } \\
6 \%\end{array}$ \\
\hline $\begin{array}{l}\text { Supply European } \\
\text { pathology } \\
\text { networks }\end{array}$ & $\begin{array}{l}\text { Information about the care path of patients } \\
\text { treated with CAR-T therapy (e.g., eligibility } \\
\text { exams, follow-up exams, monitoring post- } \\
\text { infusion) are not entered in European } \\
\text { pathology networks (e.g., ProMISe) } \\
6 \%\end{array}$ & $\begin{array}{l}\text { Some information about the care path of } \\
\text { patients treated with CAR-T therapy (e.g., } \\
\text { eligibility exams, follow-up exams, monitoring } \\
\text { post-infusion) are entered in European } \\
\text { pathology networks (e.g., PromISe) } \\
0 \%\end{array}$ & $\begin{array}{l}100 \% \text { of information about the care path of } \\
\text { patients treated with CAR-T therapy and almost } \\
90 \% \text { of follow-up information are entered in } \\
\text { European pathology networks (e.g., ProMISe) } \\
17 \%\end{array}$ & $\begin{array}{c}100 \% \text { of information about the care path of } \\
\text { patients treated with CAR-T therapy and } 100 \% \\
\text { of follow-up information are entered in } \\
\text { European pathology networks (e.g., ProMISe) } \\
77 \%\end{array}$ \\
\hline Supply of EHR & $\begin{array}{l}\text { No supply of Electronic Health Record } \\
\qquad 61 \%\end{array}$ & $\begin{array}{l}\text { Main information about the care path of the } \\
\text { patient treated with the CAR-T therapy (e.g., } \\
\text { eligibility exams, follow-up exams, post-infusion } \\
\text { monitoring) are entered in the HER } \\
11 \%\end{array}$ & $\begin{array}{l}\text { Main information about the care path of the } \\
\text { patient treated with the CAR-T therapy and } \\
\text { some additional information (e.g., eligibility } \\
\text { exams, follow-up exams, post-infusion } \\
\text { monitoring) are entered in the HER } \\
22 \%\end{array}$ & $\begin{array}{l}\text { All information about the care path of the } \\
\text { patient treated with the CAR-T therapy (e.g., } \\
\text { eligibility exams, follow-up exams, post-infusion } \\
\text { monitoring) are entered in the HER } \\
6 \%\end{array}$ \\
\hline
\end{tabular}

Fig. 4 - Digital support macro-category: description of different maturity steps for each variable and rates of centers for each variable and maturity level. 


\begin{tabular}{|c|c|c|c|c|}
\hline & 1 & 2 & 3 & 4 \\
\hline $\begin{array}{l}\text { Hub \& Spoke: } \\
\text { Presence of } \\
\text { agreements }\end{array}$ & $\begin{array}{l}\text { The Hub center has no agreements with } \\
\text { other medical centers regarding the care } \\
\text { path of the patient treated with CAR-T } \\
\text { therapy } \\
6 \%\end{array}$ & $\begin{array}{l}\text { The Hub center has informal agreements } \\
\text { with other medical centers, for example for } \\
\text { reporting patients potentially eligible for the } \\
\text { CAR-T therapy } \\
88 \%\end{array}$ & $\begin{array}{c}\text { The Hub center has formal agreements with } \\
\text { a Spoke center for the delegation of at least } \\
\text { one among: carrying out the eligibility exams; } \\
\text { carrying out the bridge therapy; carrying out } \\
\text { the follow-up checks } \\
6 \%\end{array}$ & $\begin{array}{l}\text { The Hub center has formal agreements with } \\
\text { a Spoke center for the delegation of at least } \\
\text { two among: carrying out the eligibility exams; } \\
\text { carrying out the bridge therapy; carrying out } \\
\text { the follow-up checks } \\
0 \%\end{array}$ \\
\hline $\begin{array}{l}\text { Hub \& Spoke: } \\
\text { phases sharing }\end{array}$ & $\begin{array}{l}\text { The Hub center manages all the phases of } \\
\text { the care path, except for those activities } \\
\text { that it is not able to manage internally (e.g. } \\
\text { serological exams) } \\
0 \%\end{array}$ & $\begin{array}{l}\text { The Hub center takes care of patients, } \\
\text { potentially eligible for the CAR-T therapy, } \\
\text { indicated by the Spoke center } \\
39 \%\end{array}$ & $\begin{array}{l}\text { Presence of a Spoke center which is required } \\
\text { to perform at least one among: carrying out } \\
\text { the eligibility exams; carrying out the bridge } \\
\text { therapy; carrying out the follow-up checks. } \\
\text { The main communications are managed } \\
\text { through structured information exchanges } \\
\text { (e.g. predefined modules) } \\
33 \%\end{array}$ & $\begin{array}{l}\text { Presence of a Spoke center which is required } \\
\text { to perform at least two among: carrying out } \\
\text { the eligibility exams; carrying out the bridge } \\
\text { therapy; carrying out the follow-up checks. } \\
\text { Furthermore, the Spoke center participates } \\
\text { in the Hub multidisciplinary meetings } \\
\qquad 28 \%\end{array}$ \\
\hline $\begin{array}{l}\text { Hub \& Spoke: } \\
\text { Communication } \\
\text { and } \\
\text { collaboration }\end{array}$ & $\begin{array}{l}\text { The Hub center has no Spoke center to } \\
\text { interact with } \\
0 \%\end{array}$ & $\begin{array}{l}\text { Communications between the Hub center } \\
\text { and the Spoke center take place in an } \\
\text { unstructured way (e.g. telephone, email, } \\
\text { Skype, ...) } \\
94 \%\end{array}$ & $\begin{array}{l}\text { Communications between the Hub center } \\
\text { and the Spoke center take place in a } \\
\text { structured way (e.g. EHR, Teleconsulting } \\
\text { platforms for sharing documents and images) } \\
6 \%\end{array}$ & $\begin{array}{c}\text { There are integrated digital systems } \\
\text { between Hub and Spoke that allow for an } \\
\text { organic and structured data management } \\
0 \%\end{array}$ \\
\hline
\end{tabular}

Fig. 5 - Hub \& Spoke network: description of different maturity steps for each variable and rates of centers for each variable and maturity level.

the documents generated through the care pathway of CAR T-cell therapy entirely (39\%) or partially (22\%); $17 \%$ of clinical sites integrated an interoperable clinical corporate repository with digital tools. Communication and collaboration instruments used between physicians were unstructured solutions in $55 \%$ of sites, while structured and dedicated tools, like the Electronic Medical Record, were used in 39\% of sites. Finally, $77 \%$ of clinical sites provided all the information about CAR T-cell therapy and follow-up to European pathology networks. By contrast, the supply of the Electronic Health Record was not planned in most clinical sites (61\%); if supplied, the record contained the minimal set of relevant information (11\%), or this minimal set plus a few additions (22\%).

\section{Hub \& Spoke network}

This category addressed the size and formalization of the existing network between the Hub sites and Spoke sites that shared the management of patients. The application of the developed MM revealed that a great proportion of clinical sites (61\%) delegated the management of one or more phases of CAR T-cell therapy to Spoke centers (Fig. 5); the remaining Hubs (39\%) took care of patients potentially eligible to CAR T-cell therapy indicated by Spoke centers. Despite this phenomenon, the accordance between Hub \& Spoke sites had an informal nature (88\%) and the communication and collaboration platforms were unstructured and based on email messages and phone calls.

\section{Maturity level of CAR T cell therapy centers}

Based on the results of the MM application, the 18 Italian clinical sites had an average level of maturity of 7.0 (maximum level: 8.3 , minimum level: 5.6, variance: 2.0 ), on a scale from

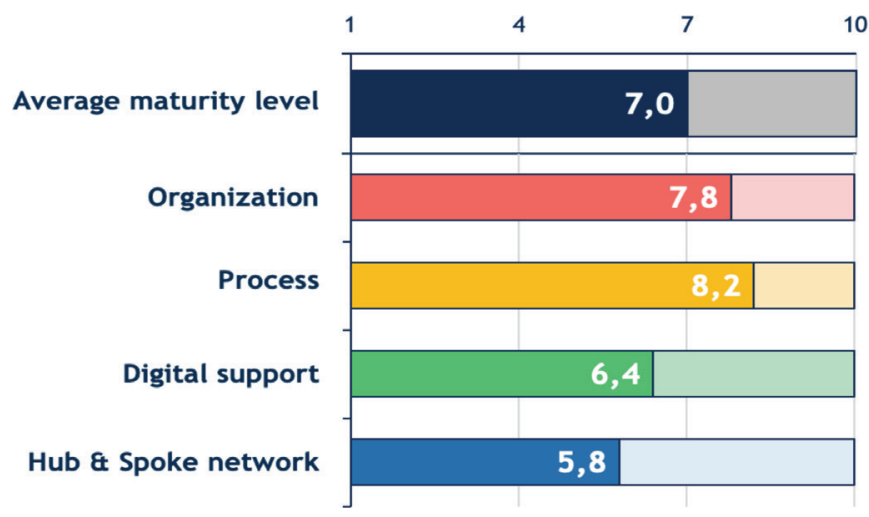

Fig. 6 - Average maturity levels of the 18 Italian clinical sites involved in the survey. Mean scores from the Maturity Model questionnaire are expressed on a scale from 1 to 10.

1 to 10 (Fig. 6). In particular, the highest scores were reached in the organization and process macro-categories, which averages respectively 7.8 (maximum level: 10.0, minimum level: 3.1, variance: 1.3 ) and 8.2 (maximum level: 10.0, minimum level: 4.2 , variance: 2.0 ). These results suggest a greater attention in the definition of organizational and procedural aspects, observed in the identification of roles within the CAR T-cell therapy unit, the coordination of activities, and the definition of specialized procedures for the care pathway of patients, in particular for the postinfusion monitoring phase. Nevertheless, improvements in these macro-categories were still possible, including the creation of dedicated spaces and delivery of training courses about CAR T-cell therapy. Digital supports available at the clinical sites were limited, with an average score of 6.4 (maximum level: 9.7, minimum level: 2.5, 
variance: 0.2 ): only a proportion of centers owned an Electronic Health Record, a Clinical Data repository, or communication instruments able to support clinical management of CAR T-cell therapy and patient care pathway. Finally, even if the development of a Hub \& Spoke network, with an average score of 5.8 (maximum level: 8.3, minimum level: 4.2, variance: 1.5$)$ was recognized as crucial by all clinical sites, improvements are needed especially in the formalization of accordance and communication between centers, and the development of collaboration tools.

\section{Conclusions}

The MM developed within the START CAR-T project may support centers that use CAR T-cell therapy in monitoring and improving management aspects, and in developing greater awareness about how organizational and procedural aspects, along with digital support, are fundamental to make this novel treatment as accessible and sustainable as possible.

As specified by de Bruin et al (7), the model will evolve as the domain knowledge and model understanding broadens and deepens. The application of the START CAR-T MM over the next years will permit to measure the improvements achieved by the various clinical sites and, at the same times, will point out what changes should be made to the $\mathrm{MM}$ in order to maintain it up-to-date and capable of supporting clinical site growth and new healthcare challenges (e.g., COVID-19 management, increased use of CAR T-cell therapy, new regulations). A deeper analysis of Spoke sites by the START CAR-T MM may also be needed: Spoke sites will be crucial for improving patient care pathways, as some of the steps of CAR T-cell therapy (bridging chemotherapy, follow-up) could be performed at Spoke sites conveniently located for patients. In the future, Spoke sites will also be likely to alleviate the work burden on Hub sites caused by the steadily increasing number of patients who will receive CAR T-cell therapy.

\section{Acknowledgments}

The authors would like to thank the following for their collaboration in this study project: Maurizio Martelli, COU Hematology, AOU Policlinico Umberto I, Rome, Italy; Federica Sorà and Simona Sica, Department of Diagnostic Imaging, Oncological Radiotherapy and Hematology, COU Hematology and Hematopoietic stem cell transplant, Fondazione Policlinico Universitario Agostino Gemelli-IRCCS, Rome, Italy; Vincenzo Perriello and Brunangelo Falini, Institute of Hematology, Ospedale S. Maria della Misericordia, Perugia, Italy; Mauro di lanni and Valentina De Thomasis, Department of Oncology and Hematology, Ospedale "Santo Spirito", Pescara, Italy; Enrico Orciuolo and Francesco Caracciolo, UO Ematologia, AOU Pisana, Ospedale Santa Chiara, Pisa, Italy; Ilaria Cutini and Riccardo Saccardi, Department of Cellular Therapies and Transfusion Medicine, A.O.U Careggi, Florence, Italy; Marco Ruggeri, Cell Therapy and Hematology, San Bortolo Hospital, Vicenza, Italy; Emanuele Angelucci, Hematologyand Transplant Center, IRCCS Ospedale Policlinico San Martino, Genova, Italy; Massimo Martino, Department of Hemato-Oncology and
Radiotherapy, Grande Ospedale Metropolitano "BianchiMelacrino-Morelli", Reggio Calabria, Italy; Maurizio Musso, Dipartimento oncologico, Unità Operativa di Oncoematologia e TMO, Ospedale La Maddalena, Palermo, Italy; Alessandro Indovina, UO Unità Trapianto di Midollo Osseo (UTMO), P.O. V. Cervello, Palermo, Italy; Marco Ladetto and Francesco Zallio, SC Ematologia, AON SANTI Antonio e Biagio e Cesare Arrigo, Alessandria, Italy; Giovanni Grillo and Roberto Cairoli, Hematology, ASST Grande Ospedale Metropolitano Niguarda, Milan, Italy; Mara Magri, Alessandro Rambaldi and Silvia Ferrari, Hematology and Bone Marrow Transplant Unit, ASST Papa Giovanni XXIII, Bergamo, Italy; Alessandro Busca and Roberto Freilone, Department of Hematology, AOU Cittá della Salute e della Scienza di Torino, Presidio Molinette, Turin, Italy; Domenico Russo, Alessandro Turra and Mirko Farina, Chair of Hematology, Bone Marrow Transplant Unit, ASST-Spedali Civili Brescia, Brescia, Italy; Armando Santoro, Humanitas University, Pieve Emanuele (Milan), IRCCS Humanitas Research Hospital, Humanitas Cancer Center, Rozzano (Milan), Italy; Consuelo Corti and Fabio Ciceri, Hematology and Bone Marrow Transplantation Unit, IRCCS San Raffaele Scientific Institute, Milan, Italy.

Editorial support was provided by Health Publishing \& Services Srl and was supported by Novartis Farma, Italy.

\section{Disclosures}

Conflict of interest: SB has nothing to disclose. MGC has nothing to disclose. ADR has nothing to disclose. EF reports to have received provisions, payment/honoraria for manuscript writing, support for travel, and medical writing/documents (property of Novartis Group) from Novartis Farma. LG has nothing to disclose. PL reports to have received provisions, payment/honoraria for manuscript writing, support for travel, and medical writing/documents (property of Novartis Group) from Novartis Farma. MCT reports payment or honoraria for lectures, presentations, speakers bureaus, manuscript writing, or educational events from Gilead and to have participated on a Data Safety Monitoring Board/Advisory Board for Novartis, Gilead, and BMS, outside the submitted work.

Financial support: This research received no specific grant from any funding agency in the public, commercial, or not-for-profit sectors.

\section{References}

1. Katz B-Z, Herishanu Y. Therapeutic targeting of CD19 in hematological malignancies: past, present, future and beyond. Leuk Lymphoma. 2014;55(5):999-1006. CrossRef PubMed

2. Greenbaum U, Mahadeo KM, Kebriaei P, Shpall EJ, Saini NY. Chimeric antigen receptor T-cells in B-acute lymphoblastic leukemia: state of the art and future directions. Front Oncol. 2020; 10:1594. CrossRef PubMed

3. Elsallab M, Levine BL, Wayne AS, Abou-El-Enein M. CAR T-cell product performance in haematological malignancies before and after marketing authorisation. Lancet Oncol. 2020;21(2): e104-e116. CrossRef PubMed

4. Gotti M, Defrancesco I, D'Angelo M, et al. Cancer immunotherapy using chimeric antigen receptor expressing T-cells: present and future needs of clinical cancer centers. Front Immunol. 2020; 11:565236. CrossRef PubMed

5. Aljurf M, Snowden JA, Hayden P, Orchard KH, McGrath E. Quality management and accreditation in hematopoietic stem cell transplantation and cellular therapy. The JACIE Guide. Online. Accessed June 9, 2021. 
6. Tarhan A, Turetken O, van den Biggelaar FJHM. Assessing healthcare process maturity: challenges of using a business process maturity model. Proceedings of the 9th International Conference on Pervasive Computing Technologies for Healthcare 2015; 344-347. Online. Accessed June 9, 2021.

7. De Bruin T, Rosemann M, Freeze R, Kulkarni U. Understanding the main phases of developing a maturity assessment model. ACIS 2005 Proceedings. Sydney, NSW, Australia. 16th Australasian Conference on Information Systems 2005; 8-19.

8. Fisher DM. The Business Process Maturity Model. A practical approach for identifying opportunities for optimization. BPTrends 2004. Online. Accessed June 9, 2021.

9. Mettler T, Rohner P, Winter R. Towards a classification of maturity models in information systems. In D'Atri A, De Marco M, Braccini AM, Cabiddu F, eds. Management of the interconnected world. Springer-Verlag: Berlin Heidelberg 2010; 333-340. CrossRef

10. Röglinger M, Pöppelbuß J, Becker J. Maturity models in business process management. Bus Process Manag J. 2012;18(2): 328-346. CrossRef

11. Iversen J, Nielsen PA, Norbjerg J. Situated assessment of problems in software development. ACM SIGMIS Database. 1999;30(2):66-81. CrossRef

12. Locatelli P, Cirilli F, Panno E, Provenzano S, Sanfilippo R, Casali P. Digital Support for Hub-and-Spoke Disease Network. Proceedings of the 12th IADIS International Conference e-Health 2020,
EH 2020-Part of the 14th Multi Conference on Computer Science and Information Systems, MCCSIS 2020; 2020: 198-202.

13. Bitter J, van Veen-Berkx E, Gooszen G, van Amelsvoort P. Multidisciplinary teamwork is an important issue to healthcare professionals. Team Perform Manage. 2013;19(5/6):263-278. CrossRef

14. Grassi MO, Furino C, Recchimurzo N, et al. Implementation of Lean healthcare methodology in designing an Intravitreal Injection Center: first Italian experience. Int Ophthalmol. 2020;40(10):2607-2615. CrossRef PubMed

15. Locatelli P, Restifo N, Gastaldi L, Sini E, Torresani M. The evolution of hospital information systems and the role of electronic patient records: from the Italian scenario to a real case. Stud Health Technol Inform. 2010;160(Pt 1):247-251. PubMed

16. Wood JC, Wood MC. W. Edwards Deming: Critical evaluation in business and management. Routledge 2005; 2:87-107.

17. Avitabile T, Boscia F, Dell'Erba A, et al. Definition of indicators of appropriateness in the management of neovascular agerelated macular degeneration: an expert opinion. Eur J Ophthalmol. 2020;30(4):795-804. CrossRef PubMed

18. Locatelli P, Facchini R, Moser R, et al. Effectively introducing mobile solutions in hospitals: the importance of process perspective and KPIs. Proceedings of the IEEE 27th International Symposium on Computer-Based Medical Systems 2014; 417-420. CrossRef 